\title{
Factors controlling rotifer abundances in a norwegian eutrophic lake : an experimental study
}

\author{
D.O. Hessen ${ }^{1}$ \\ J.P. Nilssen'
}

Keywords : Rotifers, Oscillations, Eutrophication, Predation, Competition.

\begin{abstract}
Strong oscillations in the rotifer community are frequently ubserved in eutrophic lakes, where rotifers are important components of the zooplank ton community. Manipulations with increased level of fertilizers, presence or absence of fish, abundances of competitors (cladocerans) and predators (Asplanchna) were performed in polyethylene-enclosures. The experiments provided evidence for pure eutrophication effects (e.g. elevated $\mathrm{pH}$ ) and predation from Asplanchna as the main controlling factors. The influence from potential competitors such as Daphnia and Bosmine was found to be of less importance, at least during these short-term experiments.
\end{abstract}

Etude expérimentale des facteurs de contrôle des abondances de Rotifères dans un lac norvégien eutrophe

Mots clés : Rotifères, Fluctuations, Eutrophisation, Prédation, Compétition.

Des fluctuations importantes dans la communauté des Rotifères sont fréquemment observées dans les lacs eutrophes où ces organismes sont un élément important de la communauté zooplanctonique. Des enceintes en polyéthylène ont été utilisées pour tester l'influence de la fertilisation, de la présence uu de l'absence de poissons ; de l'abondance de compétiteurs (Cladocères) et de prédateurs (Asplanchna). Ces expériences démontrent que les effets de l'eutrophisation (p. ex. l'élévation du $\mathrm{pH}$ ) et la prédation par Asplanchna sont les principaux facteurs de contrôle. L'influence des compétiteurs potentiels. tels Daphnia et Bosmina, apparait moins importante, au moins pendant ces expériences de courte durée.

\section{Introduction}

Rotifers may significantly contribute to zooplankton biomass in freshwater localities (Makarewicz \& Likens 1980), and seems to increase in relative abundance during eutrophication (Hillbricht-Ilkowska 1977). This may partly be due to the changed nutrient conditions giving increased bacterial biomass or reduced competition due to removal of cladocerans by planktivore fish which usually increase their numbers (cf. Hall \& al. 1970, Nilssen 1978, Neill 1984, Gilbert \& Stemberger 1985). Thus, rotifers may form important links in the pelagic food-web in eutrophic localities, responsible for a considerable turn-over of bacteria and algae, and a major food source for invertebrate predators (Makarewicz \& Likens 1980).

1. University of Oslo, Department of biology, Division of zoology, P.O. Box 1050, Blindem 0316 OSLO 3, NORWAY.
The large oscillations both in total numbers and species dominance, frequently recorded during eutrophic conditions (Nilssen 1978) are thus of interest not only to the rotifer community, but too the whole pelagic food web. Factors causing this oscillations, except shortage of adequate food, is scarcely investigated. In this experiment, we designated several enclosures with different biotic conditions and different nutrient levels, in order to assess some of the factors responsible for the sudden changes within the rotifer community.

\section{1. - Materials and methods}

The investigations were performed in Lake Gjersjoen $\left(A_{o}=2.7 \mathrm{~km}^{2}, Z_{m}=63 \mathrm{~m}\right)$. S.E. Norway.

The lake is at present in a state of recovery from beeing highly eutrophic in the 1960s. The lake has been monitored for more than 30 years, and from the oligotrophic phase in the early 1950s to the eutrophic peak in the early 1970s, large changes was 
observed in the rotifer community (Faafeng \& Nilssen 1981). During the last decade, large schools of juvenile roach (Rutilus rutilus) strongly supresses the larger and medium sized crustaceans (Hessen 1985). At present, the dominant crustaceans in the epilimnion are the small cladoceran Bosmina longirostris and the cyclopoid copepods Thermocyclops oithonoides and Mesocyclops leuckarti.

Experiments were carried out during two onemonth experimental periods, a summer experiment 1.-28. august 1980 , and a spring experiment 2. May - 19. June 1981. In each of the experiments we used 6 polyethylene enclosures with diameter $1.5 \mathrm{~m}$ and depth $4 \mathrm{~m}$, tied to a wooden framework in the pelagic zone above $25 \mathrm{~m}$ depth. The bags were filled with lake water by use of a water pump, and we added zooplankton from vertical net-hauls $20-0 \mathrm{~m}$ ( $45 \mu \mathrm{m}$ net).

In each of the series, one bag was kept unchanged as control (C), one bag was added nutrients to increase algal biomasse $(\mathrm{N})$, two bags were added fish $(\mathrm{F})$, one was added nutrients and fish $(\mathrm{N}+\mathrm{F})$ and the last bag added fertilizer and the efficient grazer Daphnia longispina $(\mathrm{N}+\mathrm{D})$.

Nutrients added, was a solution of ammonium nitrate and ammonium dihydrogen phosphate giving a final concentration of $3200 \mu \mathrm{g}^{-1} \mathrm{NO}_{3} \mathrm{~N}$ and 600 $\mu \mathrm{gl}^{-1} \mathrm{PO}_{4}-\mathrm{P}$. The fish added was roach fry, $\mathrm{O}+$ and $1+, 12-15$ ind per bag. The large filtrator, Daphnia longispina, due to strong fish predation pressure not naturally occuring in the lake, was collected in a nearby lake and added in numbers corresponding to about 1 ind. $\mathrm{l}^{-1}$ in the bags. (I. e. $7000 \mathrm{ind} / \mathrm{bag}$ ).

Samples were taken with a modified van Dorn sampler from depths $0,1,2$ and $4 \mathrm{~m}$, and mixed. Phytoplankton and bacteria was taken directly from this mixed sample, while two replicates of $5 \mathrm{l}$ each were filtered through a $45 \mu \mathrm{m}$ net for zooplankton collection. Zooplankton samples were taken twice a week, while phytoplankton samples were taken at the beginning, middle and end of the experiment. Bacterial biomass was only calculated in the spring experiment. $\mathrm{pH}$ and temperature was measured on each sampling date, chlorophyll once a week. Oxygen contents was measured at the termination of the experiments to reveal a possible oxygen depletion.

Phytoplankton and zooplankton were fixed with acid Lugol and counted by use of the Utermöhl (1958) technique and on a counting tray, respectively.
Bacteria were fixed with formalin ( $2 \%$ final concentration), stained and counted by use of the fluorescence technique. (Hobbie \& al. 1977). Calculations of algal biomass was done with geometrical models, while bacterial biomass was estimated by use of a micrometer scale ocular.

\section{2. - Results}

Temperature was identical within bags and the lake. $\mathrm{pH}$, however showed elevated levels in fertilized bags during summer, due to a strong rise in algal biomass (fig. 1). In summer, $\mathrm{pH}$ exceeded 10.5 in fertilized bags, compared to about 9.5 in the unfertilized ones. In spring the differencies in $\mathrm{pH}$ between fertilized and unfertilized bags was insignificant.

The phytoplankton community was dominated by large species like Oscillatoria agardhii and Synedra sp. together with Rhodomonas lacustris, Scenedesmus spp. and Chrysomonas except for fertilized bags in summer in which large amounts of small unidentified coccoid green algae was recorded. The phytoplankton was divided in three groups : $<15 \mu \mathrm{m}$, (probably available both to crustaceans and rotifers), $15-50 \mu \mathrm{m}$, (edible by most species of adult crustaceans but probably too large to small rotifers like Keratella cochlearis, Pompholyx sulcata and Kellicottia longispina) (Pejler 1957, Pourriot 1977) and larger than $50 \mu \mathrm{m}$, probably too large to most species of zooplankton (Burns 1968, Gliwicz 1975).

In spring, the groups of small and medium sized algae constituted less than $1.8 \mathrm{~mm}^{3} \mathrm{l}^{-1}$ during the whole experimental period (Tab. 1). The smallest algae ( $<15 \mu \mathrm{m}$ ) became almost extinct in all bags. In the surnmer experiment, higher biomasses of small algae was recorded compared to spring, although they remained relatively scarce in unfertilized bags. In fertilized bags, they showed a rapid increase, with exception of the bag added Daphnia longispina, where they probably were checked due to grazing.

Bacterial numbers showed a strong increase in fertilized bags, including the Daphnia-bag, in spring, giving final concentrations of more than $5.5 .10^{6}$ cells $\mathrm{ml}^{-1}$, compared to a mean of $2.8 .10^{6}$ in unfertilized bags added fish, and $1.5 .10^{6}$ in the control bag (1.9.10 in the lake). With an estimated mean cell volume of $0.1 \mu^{3}$, the bacterial biomass in the fertilized bags corresponds to ca. $0.5-0.6 \mathrm{~mm}^{3} \mathrm{l}^{-1}$, thus exceeding biomass of small algae in these bags. 


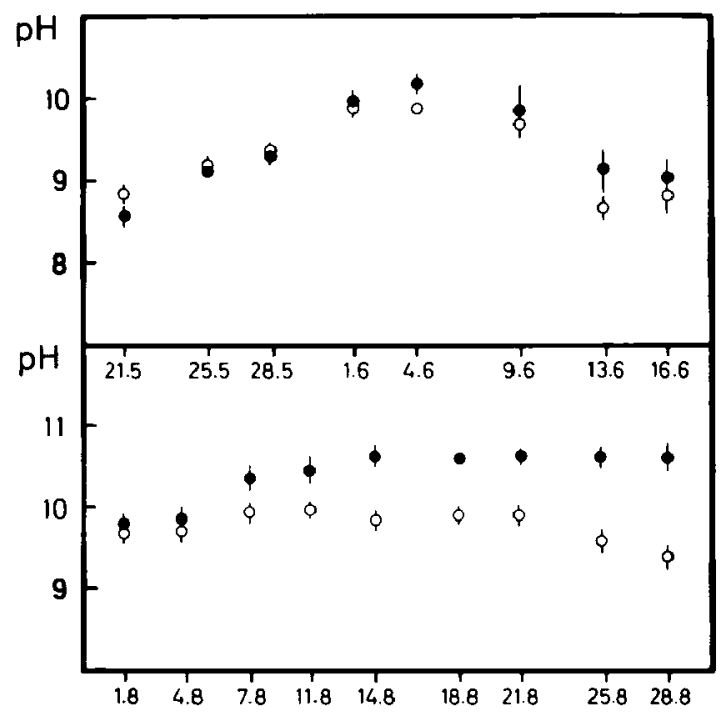

Fig. 1. pH in unfertilized (open circles) and fertilized bags (filled circles). S.D. as vertical bars. Table 1. Biomass $\left(\mathrm{mm}^{3} \mathrm{l}^{-1}\right)$ of different size classes of algae $C$ : control, $F_{1}$ and $F_{2}$ : added fish, $N$ : nutrients, $N+F$ : nutrients and fish, $N+D$ : nutrients and Daphnia.

\begin{tabular}{|c|c|c|c|c|c|c|c|}
\hline Bag & size, $\mu \mathrm{m}$ & 21.5 & 1.6 & 16.6 & 1.8 & 14.8 & 28.8 \\
\hline C & $\begin{array}{l}<15 \\
15-50 \\
>50\end{array}$ & $\begin{array}{l}1.6 \\
0.3 \\
1.3\end{array}$ & $\begin{array}{l}0.6 \\
0.1 \\
5.7\end{array}$ & $\begin{array}{l}0.4 \\
0.1 \\
3.1\end{array}$ & $\begin{array}{l}0.6 \\
0.2 \\
1.8\end{array}$ & $\begin{array}{l}0.6 \\
0.1 \\
0.8\end{array}$ & $\begin{array}{l}1.2 \\
0.1 \\
0.2\end{array}$ \\
\hline$F_{1}$ & $\begin{array}{l}<15 \\
15-50 \\
>50\end{array}$ & $\begin{array}{l}1.7 \\
0.3 \\
1.9\end{array}$ & $\begin{array}{l}0.8 \\
0.1 \\
9.1\end{array}$ & $\begin{array}{c}0.1 \\
. \\
14.2\end{array}$ & $\begin{array}{l}0.8 \\
0.1 \\
1.5\end{array}$ & $\begin{array}{l}0.4 \\
0.2 \\
1.2\end{array}$ & $\begin{array}{r}0.5 \\
.0 .5 \\
0.9\end{array}$ \\
\hline$F_{2}$ & $\begin{array}{l}<15 \\
15-50 \\
>50\end{array}$ & $\begin{array}{l}1.5 \\
0.7 \\
0.6\end{array}$ & $\begin{array}{r}0.5 \\
0.7 \\
13.4\end{array}$ & & $\begin{array}{l}0.6 \\
0.4 \\
2.8\end{array}$ & $\begin{array}{l}0.9 \\
0.2 \\
1.1\end{array}$ & $\begin{array}{l}0.6 \\
0.5 \\
1.5\end{array}$ \\
\hline $\mathbf{N}$ & $\begin{array}{l}<15 \\
15-50 \\
>50\end{array}$ & $\begin{array}{l}0.4 \\
1.3 \\
1.6\end{array}$ & $\begin{array}{l}- \\
0.2 \\
1.1\end{array}$ & $\begin{array}{l}- \\
0.4 \\
3.0\end{array}$ & $\begin{array}{l}0.5 \\
0.6 \\
3.4\end{array}$ & $\begin{array}{l}3.2 \\
0.1 \\
8.4\end{array}$ & $\begin{array}{l}3.9 \\
5 \\
5.1\end{array}$ \\
\hline $\mathbf{N}+\mathbf{F}$ & $\begin{array}{l}<15 \\
15.50 \\
>50\end{array}$ & $\begin{array}{l}1.2 \\
0.4 \\
1.4\end{array}$ & $\begin{array}{r}0.3 \\
1.8 \\
12.4\end{array}$ & $\begin{array}{l}0.3 \\
i .4\end{array}$ & $\begin{array}{l}0.9 \\
0.2 \\
2.3\end{array}$ & $\begin{array}{l}4.5 \\
6.0 \\
1.1\end{array}$ & $\begin{array}{r}10.0 \\
5.1 \\
1.6\end{array}$ \\
\hline$N+D$ & $\begin{array}{l}<15 \\
15-50 \\
>50\end{array}$ & $\begin{array}{l}1.2 \\
0.6 \\
3.4\end{array}$ & $\begin{array}{l}0.2 \\
0.1 \\
8.4\end{array}$ & $\begin{array}{l}0.5 \\
- \\
5.1\end{array}$ & $\begin{array}{l}1.1 \\
0.6 \\
3.4\end{array}$ & $\begin{array}{l}0.3 \\
0.1 \\
8.4\end{array}$ & $\begin{array}{l}0.5 \\
5.1\end{array}$ \\
\hline
\end{tabular}




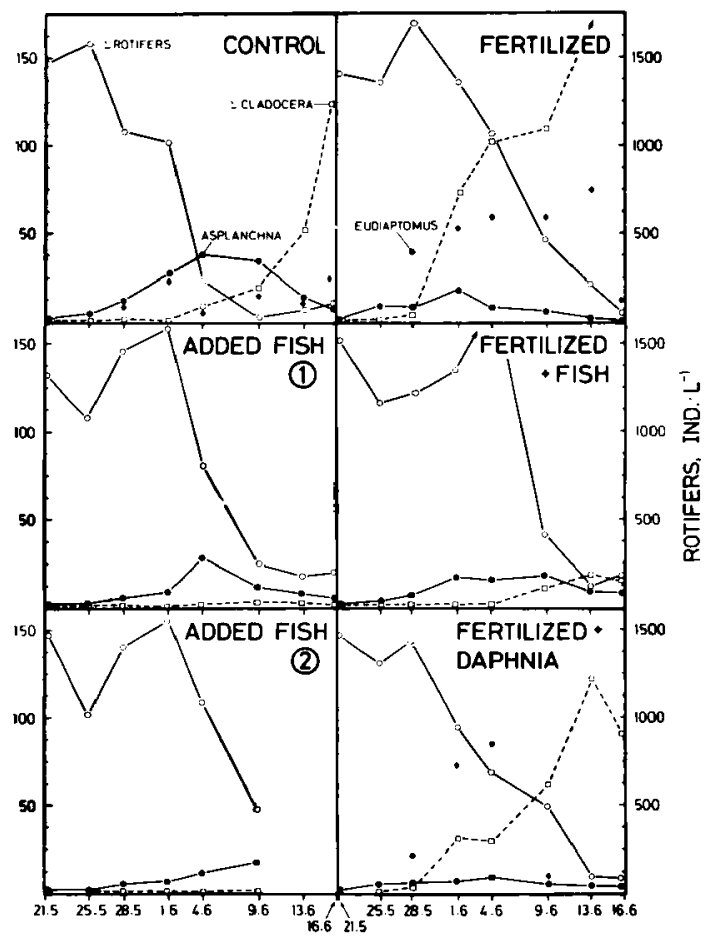

Fig. 2. Development of rotifers and cladocerans in different bags during the spring experiment. $\Sigma$ Rotifers includes all rotifers except Asplanchna. $\Sigma$ Cladocera are mainly Bosmina longispina and B. longirostris, and Daphnia longispina as indicated in one bag. The herbivore calanoid copepod Eudiaptomus gracilis is indicated when present in any number.

In the spring experiment, maximum rotifer number occured within the first week in most bags, followed by a sharp decrease to almost extinction in the last half of the experiment (fig. 2). Keratella cochlearis made up about $70-90 \%$ of rotifer numbers, with Keratella quadrata, Kellicottia longispina, Polyarthra dolichoptera, and Synchaeta pectinata as subdominants. With exeption of Asplanchna, all species showed an almost similar response in numerical development. Asplanchna priodonta became most abundant in the last half of the experiment in all bags with a maximum recorded number of almost 400 ind. $1^{-1}$ in the control bag.
Crustaceans responded strongly to the additions of fish, as all cladocerans and all large developmental stages of calanoid and cyclopoid copepods almost disappeared (Hessen 1985). In the three bags without fish. cladocerans, mainly Bosmina longirostris became abundant, as did the calanoid Eudiaptomus gracilis. Daphnia longispina showed a strong increase in the bags to which it was added. Cyclopoid copepods, not included in fig. 2 , remained in relatively low numbers in all bags. The predatory stages (cop. IV-ad.), only occationally exceeded 10 ind. $1^{-1}$ in any bag, completely dominated by the small Thermocyclops oithonoides. Nauplii (mainly 


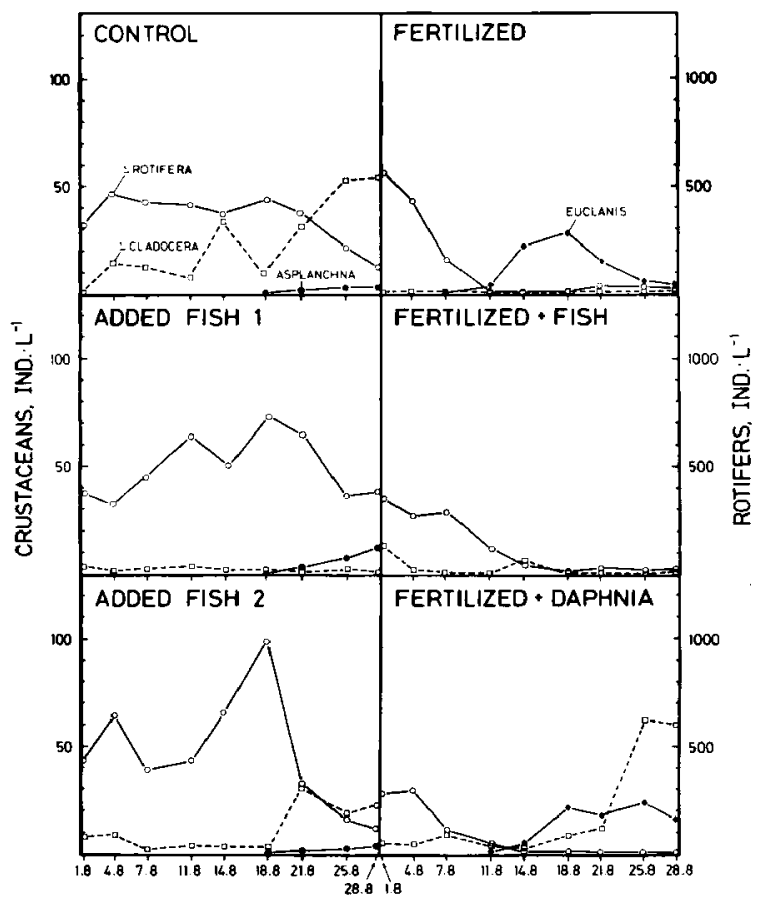

Fig. 3. Development of rotifers and cladocerans in different bags during the summer experiment. Symbols as is fig. 2.

cyclopoids) were abundant in all bags, with a peak in the middle of the experiment with numbers of 36-112 ind. $\mathrm{l}^{-1}$.

In summer, rotifer number showed strong oscillations in all bags, with a tendency for numerical decrease towards the end of the experiment (fig. 3). In the fertilized bags, however, a sharp decline to almost extinction was recorded within the first half of the experiment. In two of the fertilized bags, Euclanis dilatata showed an immediate population growth following the decline of the other species. As in spring, Keratella cochlearis was the most abun. dant species, with Synchaeta pectinata, Trichocerca pusilla and Pompholyx sulcata as subdominants. All species following the same main development. Asplanchna priodonta was only found in any number in the control bag, and one of the unfertilized bags, added fish (cf. fig. 3).

The crustacean response to addition of fish was less pronounced than in spring, although most crustaceans was strongly checked in bags added fish. Bosmina longirostris became abundant in the control bag, and in the bag added Daphnia longispina, where also the latter species showed a strong increase. Eudiaptomus gracilis was scarce in all bags. Larger developmental stages of cyclopoids were also found 
in low numbers in all bags $\left(0-10.1^{-1}\right)$, with exception of the fertilized bags without fish, where Mesocyclops leuckarti became abundant in the last week ( $>20$ ind. $\mathrm{l}^{-1}$ ) and the fertilized bag added Daphnia, where both Mesocyclops and Thermocyclops became abundant towards the end of the experiment $\left(>30\right.$ ind. $\mathrm{I}^{-1}$ ).

Percent egg-carrying individuals of the dominant rotifers is shown in tab. 2 and 3 . In spring a sudden drop in percent egg-carrying individuals reaching a mid-experiment minimum was found, although somewhat increasing towards the end of the experiment in most bags. In summer, with a total dominance of Keratella cochlearis, percent egg-carrying individuals of this species remained more or less constant in unfertilized bags, but soon dropped to almost zero in fertilized ones.

\section{3. - Discussion}

Several factors may have caused the observed responses in the rotifer community during these experiments. Four reasons, or combinations of these, could be responsible for the main events.

1) Invertebrate predation (mainly by Asplanchna)

2) Resource limitation, partly due to competition from herbivorous crustaceans

3) Environmental stress due to extreme $\mathrm{pH}$-values

4) Release of toxic substances by algae.

Asplanchna priodonta became abundant in all bags during the spring experiment, synchronously with the decline of the other rotifers (cf. fig. 2), Asplanchna spp. are omnivorous, although having a dietary preference for small rotifers, particularily Keratella cochlearis, (Pourriot 1977) but also Synchaeta pectinata and Trichocerca pusilla (Ejsmont-Karabin 1975, Gilbert \& Williamson 1978, Gilbert 1980), thus all the main species in these experiments are subject to predation by Asplanchna. In the bags, a relationship of prey-rotifers and Asplanchna is about $1: 20-1: 30$ at the rotifer peak, and the decline indicates a consumption of roughly 2-5 rotifer day ${ }^{-1}$ or 3-7 day ${ }^{-1}$ when corrected for production, assuming that other predators are of minor importance. This seems reasonable compared to other studies (cf. Stemberger \& Gilbert 1984).

The ability of Asplanchna to control the structure of rotifer communities is suggested by other authors (Edmondson 1960, Lewcowicz 1971, Zimmerman 1974).
However, egg production declined during the first half of the experimental period as well. This might be caused by higher predation on egg-carrying individuals due to their reduced escape abilities, or reduced food availability allocated to reproduction. The decrease in small algae ( $<15 \mu \mathrm{m}$ ) (cf. Tab. 2), occurred simultaneously with decreased egg production. This is not a sufficient explanation however, as the most rapid decline in rotifers occurred in the control bag, in which the highest biomass of small algae was recorded. The increase in egg production towards the end of the experiment in all bags, could partly be explained by increased bacterial biomass, especially in fertilized bags and in reduced numbers of Asplanchna.

Thus, the most reasonable explanation on the decline in rotifer numbers in spring is Asplanchna predation, combined with a decline in the most valuable algal species.

In summer, the immediate decline in both number and egg production in fertilized bags closely follows the sharp pH-rise. There is only scarce information on the effect of high pH on zooplankton. Bogatova (1961), Ivanova (1969) and Walter (1965) all found an upper $\mathrm{pH}$ limit for cladocerans around 10.5-11.5. The negative effect of such high $\mathrm{pH}$ on Thermocyclops oithonoides is discussed by Hessen \& Nilssen (1984). All crustaceans seemed to suffer from these extreme $\mathrm{pH}$ values, with exeption of Mesocyclops leuckarti and Daphnia longispina. During the peak eutrophication in Lake Gjersjфen, $K$. cochlearis remained in high densities, while the other rotifers disappeared (Faafeng Nilssen 1981). At this peak, maximum epilimnetic pH only occationally exceeded 9.5. Euclanis dilatata was the only rotifer which could withstand $\mathrm{pH}$ of 10.5 , and even increase in fertilized bags (fig. 3). Release of algal toxins was not likely to cause the observed rotifer decline in fertilized bags, as composition of bluegreens and other suspected toxic algae was almost similar in fertilized and unfertilized bags (see discus. sion in Hessen \& Nilssen 1984).

The number of small algae remained low, although constant or even increasing in unfertilized bags. Eggproduction was almost identical in these bags, and nemained high throughout the experiments. The observed changes in rotifer numbers in the unfertilized bags are probably caused by the increasing Asplanchna population. Asplanchna was only occasionally found in fertilized bags. 
Table 2. Percent egg-carrying individuals of Keratella cochlearis (K.c.), Keratella quadrata (K.q.) and Kelicottia longispina (K.l.) in spring. Symbols as in tab. 1.

\begin{tabular}{|c|c|c|c|c|c|c|c|c|c|}
\hline Bag & Spec. & 21.5 & 25.5 & 28.5 & 1.6 & 4.6 & 9.6 & 13.6 & 16.6 \\
\hline C & $\begin{array}{l}\text { K.c. } \\
\text { K.q. } \\
\text { K.l. }\end{array}$ & $\begin{array}{l}57 \\
31 \\
28\end{array}$ & $\begin{array}{r}32 \\
21 \\
5\end{array}$ & $\begin{array}{r}21 \\
3 \\
0\end{array}$ & $\begin{array}{r}17 \\
3 \\
0\end{array}$ & $\begin{array}{r}13 \\
0 \\
0\end{array}$ & $\begin{array}{c}36 \\
\cdot \\
.\end{array}$ & $\begin{array}{c}22 \\
- \\
-\end{array}$ & $\begin{array}{c}43 \\
\cdot \\
.\end{array}$ \\
\hline$F_{1}$ & $\begin{array}{l}\text { K.c. } \\
\text { K.q. } \\
\text { K.l. }\end{array}$ & $\begin{array}{l}54 \\
35 \\
48\end{array}$ & $\begin{array}{l}42 \\
23 \\
41\end{array}$ & $\begin{array}{l}32 \\
13 \\
24\end{array}$ & $\begin{array}{r}34 \\
2 \\
11\end{array}$ & $\begin{array}{r}30 \\
0 \\
-\end{array}$ & $\begin{array}{r}23 \\
0\end{array}$ & $\begin{array}{r}33 \\
0 \\
0\end{array}$ & $\begin{array}{r}35 \\
0 \\
39\end{array}$ \\
\hline$F_{2}$ & $\begin{array}{l}\text { K.c. } \\
\text { K.q. } \\
\text { K.I. }\end{array}$ & $\begin{array}{l}57 \\
43 \\
29\end{array}$ & $\begin{array}{l}42 \\
32 \\
38\end{array}$ & $\begin{array}{l}28 \\
15 \\
15\end{array}$ & $\begin{array}{r}25 \\
8 \\
10\end{array}$ & $\begin{array}{r}19 \\
0 \\
0\end{array}$ & $\begin{array}{r}20 \\
13 \\
0\end{array}$ & & \\
\hline $\mathrm{N}$ & $\begin{array}{l}\text { K.c. } \\
\text { K.q. } \\
\text { K.l. }\end{array}$ & $\begin{array}{l}53 \\
32 \\
47\end{array}$ & $\begin{array}{l}36 \\
20 \\
25\end{array}$ & $\begin{array}{r}23 \\
8 \\
3\end{array}$ & $\begin{array}{l}7 \\
0 \\
0\end{array}$ & $\begin{array}{l}8 \\
0 \\
0\end{array}$ & $\begin{array}{c}36 \\
0 \\
-\end{array}$ & $\begin{array}{r}55 \\
0 \\
.\end{array}$ & $\begin{array}{c}34 \\
0 \\
-\end{array}$ \\
\hline $\mathbf{N}+\mathbf{F}$ & $\begin{array}{l}\text { K.c. } \\
\text { K.q. } \\
\text { K.1. }\end{array}$ & $\begin{array}{l}54 \\
23 \\
48\end{array}$ & $\begin{array}{l}43 \\
19 \\
28\end{array}$ & $\begin{array}{l}35 \\
10 \\
43\end{array}$ & $\begin{array}{r}22 \\
22 \\
0\end{array}$ & $\begin{array}{r}38 \\
16 \\
0\end{array}$ & $\begin{array}{r}42 \\
50 \\
0\end{array}$ & $\begin{array}{r}32 \\
0 \\
33\end{array}$ & $\begin{array}{r}42 \\
0 \\
66\end{array}$ \\
\hline$N+D$ & $\begin{array}{l}\text { K.c. } \\
\text { K.q. } \\
\text { K.t. }\end{array}$ & $\begin{array}{l}52 \\
24 \\
21\end{array}$ & $\begin{array}{l}43 \\
29 \\
33\end{array}$ & $\begin{array}{r}33 \\
10 \\
0\end{array}$ & $\begin{array}{r}28 \\
3 \\
0\end{array}$ & $\begin{array}{l}6 \\
6 \\
-\end{array}$ & $\begin{array}{r}7 \\
12 \\
0\end{array}$ & $\begin{array}{r}23 \\
0 \\
.\end{array}$ & 24 \\
\hline
\end{tabular}

Table 3. Percent egg-carrying individuals of Keratella cochlearis in summer. Symbols as in tab. 3.

\begin{tabular}{ccccccccccc}
\hline Bag & Spec. & 1.8 & 4.8 & 7.8 & 11.8 & 14.8 & 18.8 & 21.8 & 25.8 & 28.8 \\
\hline C & K.c. & 36 & 34 & 22 & 28 & 40 & 18 & 19 & 20 & 43 \\
F $_{1}$ & K.c. & 14 & 41 & 25 & 22 & 30 & 20 & 22 & 14 & 23 \\
F $_{2}$ & K.c. & 28 & 36 & 20 & 39 & 42 & 38 & 39 & 24 & 43 \\
N & K.c. & 17 & 36 & 1 & 10 & 0 & 0 & 8 & 11 & 11 \\
N + F & K.c. & 18 & 32 & 7 & 0 & 8 & 6 & 20 & 0 & 10 \\
N + D & K.c. & 13 & 40 & 5 & 19 & 3 & 0 & 0 & 0 & 0 \\
\hline
\end{tabular}

It is a generally hold belief that cladoceran densities are the main regulating factor of rotifers, linked to competition for bacteria and small algae (Comita 1972, Neill 1984) or « interference competition" (Gilbert \& Stemberger 1985), and that a removal of large cladocerans' by fish predation improves the conditions for rotifers in eutrophic lakes (Hall \& al. 1970, Nilssen 1978, Lynch 1979). This is supported by the observations of long term changes in Lake Gjersjoen (Faafeng \& Nilssen 1981). The roach fry in lake Gjersjoen mainly consumes cladocerans, but in addition high numbers of advanced and adult copepods (Hessen 1985). Rotifers, even Asplanchna is totally avoived. During this short term experiments, both egg production and total number of rotifers was significantly higher during the mid-part of the experiments in bags added fish (fig. 4). In these bags, the crustacean competitors except nauplii and small copepodids, were almost completely eliminated. In spite of this, the biomass development of small algae did not differ significantly between bags with and without cladocerans, and the reason for lower rotifer productivity in the fish-free enclosures is at least not a straight-forward result of resource competition.

To summarize, a set of biotic and abiotic factors seems to be involved in the regulation of density and species composition within the rotifer community. While predation from the carnivorous Asplanchna 


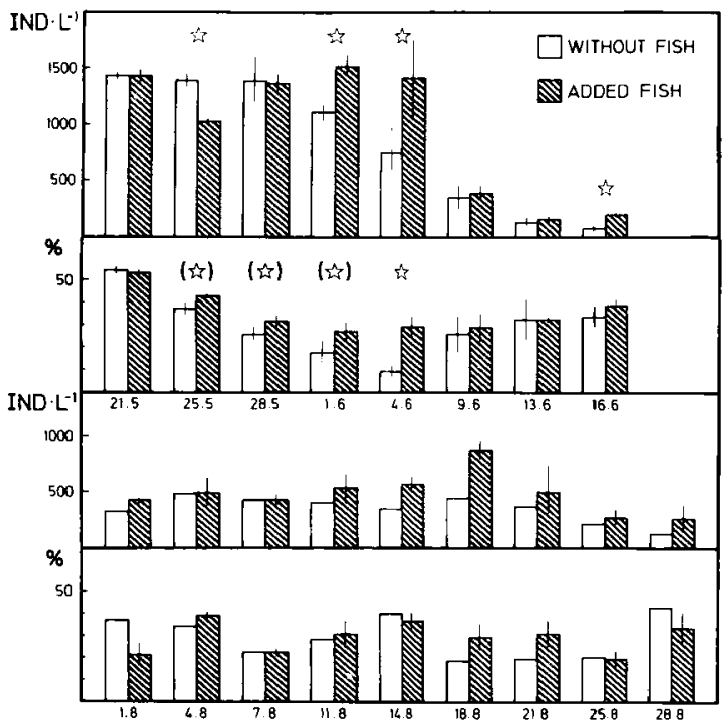

Fig. 4. Total number of rotifers and percent egg-carrying individuals of the dominant rotifer Keratella cochlearis in bags with and without fish. Upper: spring, lower: summer. In the summer experiment, only unfertilized bags are included.

Level of significance (T-test) in difference indicated by asteriscs. . * : p <0.05-(*) : p <0.2

appeared as the most important factor in spring, pure entrophication factors as $\mathrm{pH}$ elevation seemed most important in summer. The effect of competition from herbivorous crustaceans, frequently referred to as the most important inhibitor to rotifers, was obscure. For periods, cladocerans seemed to suppress the rotifers, but only in spring this was associated with a depletion of the nanno. phytoplankton.

\section{Acknowledgement}

This study was financially supported by the Norwegian Council for Technical and Natural Research, as part of a research program on eutrophication of inland waters. We acknowledge Aage Brabrand, Bjorn Faafeng and Tone Oksum Eriksen for helpful assistance and discussion during the run of this experiment.

\section{References}

Bogatova (I.B.). 1962. - Lethal ranges of oxygen content, tempe rature and $\mathrm{pH}$ for some representatives of the family Chydoridae. Zool. Zh., $41: 58-62$.

Bums (C.W.). 1968 . - The relationship between body size of filterfeeding Cladocera and the maximum size of particle inges ted. Limnol. Oceanogr., $13: 675.678$.

Comita (G.W.). 1972. - The seasonal zooplankton cycles, production and transformation of energy in Severson Lake, Minnesota. Arch. Hydrobiol., 70: 14-66.

Edmondson (W.T.) 1960. - Reproductive rates of rotifers in natural populations. Mem. Ist. Ital. Idrobiol., 12 : 21.77.

Ejsmont-Karabin (J.). 1974. - Studies on the feeding of the planktonic polyphage Asplanchna priodonta Gosse (Rotatoria). Ekol. Pol., 22 : $311-317$.

Faafeng (B.) \& Nilssen (J.P.). 1981. - A twenty year study of eutro phication in a deep, soft water lake. Int. Ver. Theor. Angew. Limnol. Verh., $21: 380-382$.

Gilbert (J.J.). 1980. - Feeding in the Rotifer Asplanchna : Beha. viour, Cannibalism, Selectivity, Prey Defenses, and Impaci on Rotifer Communities. In : Kerfoot (W.C.) : Evolution and Ecology of Zooplankton Cornmunities. p. 158-172. 
Gilbert (J.J.) \& Williamson (C.E.). 1979. - Predator-prey behaviour and its effects on rotifer survival in associations of Mesocyclopsedax, Asplanchna girodi, Polyarthra velgaris and Keratella cochlaris. Oecologia, $37: 13-22$

Gilbert (J.J.) \& Stemberger (R.S.). 1985. - Control of Keratella populations by interference comptetition from Daphnia. Lim. nol. Oceanogr., 30:180-189.

Gliwicz (Z.M.). 1977. - Food size selection and seasonal succession of filter feeding zooplankton in a eutrophic lake. Ekol. Pol. $25: 179.225$

Hall (D.J.), Cooper (W.E.) \& Werner (E.E.). 1970. - An experimental approach to the production dynamics and structure of freshwater animal communities. Limnol. Oceanogr., 15: $839-928$.

Hessen (D.O.). 1985, - Selective zooplankton predation by preadult roach (Rutilus ruilus) : The size-selective hypothesis versus the visibility - selective hypothesis. Hydrobiologia, 124 : $73-79$.

Hessen (D.D.) \& Nilssen (J.P.). 1984. - High $\mathrm{pH}$ and the abundances of two commonly co-occurring freshwater copepods (Copepoda, Cyclopoida). Annls. Limnot, 19: 195-201.

Hillbricht-Ilkowska (A.). 1977. - Trophic relations and energy flow in pelagic plankton. Pol Ekol. Stud., 3:3-98.

Hobbic (J.E.). Daley (R.J.) \& Jasper (S.). 1977. - Lise of nucleopore filters for counting bacteria by fluorescent micruscopy. Appl. Environ. Microbiol., $33: 1225-1228$.

Ivanova (M.B.). 1969 . - The influence of active water reaction on filtering rate of cladocera. Pol. Arch. Hydrobiol., 16: 115-124.
Lewkowicz (M.). 1971. - Biomass of zooplankton and production of some species of Rotatoria and Daphnia longispina in carp ponds. Pol. Arch. Hydrobiol., 18 : 215-223.

Lynch (M.). 1979, - Predation, competition, and zooplankton community structure: An experimental study. Limnol. Oceanogr., $24: 252-272$

Macarewicz (J.C.) \& Likens (G.). 1979. - Structure and function of the zooplankton community of Mirror Lake, New Hanphire. Ecol. Monogr., 49 : 109-127.

Neill (W.E.). 1984. - Regulation of rotifer densities by crustacean zooplankton in an ol igotrophic montane lake in British Colombia. Oecologia, 61: 175-181.

Nilssen (J.P.). 1978. - Eutrophication, minute algae and inefficient grazers. Mem. Ist. Ital. Idrobiol., $36: 121.138$.

Pejler (B.) 1957. - Taxonomical and ecological studies on planktonic Rotatoria from northern swedish Lappland. $K$. Svenska Velensk, Akad. Handl. 6, 5: 1-68

Pourriot (R.). 1977. - Food and feeding habits of Rotifera. A rch. Hydrobial. Beih. 8 : 243-260.

Stemberger (R.S.) \& Gilbert (J.J.). 1984. - Body size, ration level, and population growth in Asplanchna. Oecologia, $64: 355-359$.

Utermöhl (F.). 1958. - Zur Vervollkommung der quantitativen Phytoplankton Methodik. Mitt. Int. Verein. Limtnol, 9 : 1-38.

Walter (B.). 1969. - Inter-relations of cladocera and algae. Ph. D. thesis. Westfield Coll. Univ. Londor.

Zimmerman (C.) 1974. - Die pelagischen Rotatorien des Sempachersees mit spezieller Berücksichtung der Brachioniden und der Ernährungsfrage. Schweiz. Z Hydrol. 36 : 205-300. 